\title{
Inclusion of brown midrib dwarf pearl millet silage in the diet of lactating dairy cows
}

\author{
M. T. Harper, ${ }^{*}$ A. Melgar, ${ }^{*}$ J. Oh, ${ }^{*}$ K. Nedelkov, $†$ G. Sanchez, $\ddagger$ G. W. Roth,§ and A. N. Hristov*1 \\ *Department of Animal Science, The Pennsylvania State University, University Park 16802 \\ †Department of Animal Husbandry, Faculty of Veterinary Medicine, Trakia University, Stara Zagora, Bulgaria 6000 \\ †Escuela Agricola Panamericana El Zamorano, El Zamorano, Honduras 93 \\ §Department of Plant Science, The Pennsylvania State University, University Park 16802
}

\begin{abstract}
Brown midrib brachytic dwarf pearl millet (Pennisetum glaucum) forage harvested at the flag leaf visible stage and subsequently ensiled was investigated as a partial replacement of corn silage in the diet of highproducing dairy cows. Seventeen lactating Holstein cows were fed 2 diets in a crossover design experiment with 2 periods of $28 \mathrm{~d}$ each. Both diets had forage: concentrate ratios of 60:40. The control diet (CSD) was based on corn silage and alfalfa haylage, and in the treatment diet, $20 \%$ of the corn silage dry matter (corresponding to $10 \%$ of the dietary dry matter) was replaced with pearl millet silage (PMD). The effects of partial substitution of corn silage with pearl millet silage on dry matter intake, milk yield, milk components, fatty acid profile, apparent total-tract digestibility of nutrients, $\mathrm{N}$ utilization, and enteric methane emissions were analyzed. The pearl millet silage was higher in crude protein and neutral detergent fiber and lower in lignin and starch than the corn silage. Diet did not affect dry matter intake or energy-corrected milk yield, which averaged $46.7 \pm 1.92 \mathrm{~kg} / \mathrm{d}$. The PMD treatment tended to increase milk fat concentration, had no effect on milk fat yield, and increased milk urea N. Concentrations and yields of milk protein and lactose were not affected by diet. Apparent total-tract digestibility of dry matter decreased from $66.5 \%$ in CSD to $64.5 \%$ in PMD. Similarly, organic matter and crude protein digestibility was decreased by PMD, whereas neutraland acid-detergent fiber digestibility was increased. Total milk trans fatty acid concentration was decreased by PMD, with a particular decrease in trans-10 18:1. Urinary urea and fecal $\mathrm{N}$ excretion increased with PMD compared with CSD. Milk N efficiency decreased with PMD. Carbon dioxide emission was not different
\end{abstract}

Received October 23, 2017.

Accepted January 26, 2018.

${ }^{1}$ Corresponding author: anh13@psu.edu between the diets, but PMD increased enteric methane emission from 396 to $454 \mathrm{~g} / \mathrm{d}$ and increased methane yield and intensity. Substituting corn silage with brown midrib dwarf pearl millet silage at $10 \%$ of the diet dry matter supported high milk production in dairy cows. When planning on farm forage production strategies, brown midrib dwarf pearl millet should be considered as a viable fiber source.

Key words: dairy cow, methane, milk fat, pearl millet silage

\section{INTRODUCTION}

Dairy farms in the northeast United States rely on homegrown forages for the foundation of their rations (Wolf, 2003). The amount and quality of the harvested forage affect profitability and hence viability of dairy farms, particularly of smaller farms ( $<200$ cows), which may have fewer economies of scale or opportunity to purchase additional hectares (Gillespie et al., 2010). Corn silage has qualities (e.g., high yield, simplicity of harvest, high energy content) that make it a popular forage for dairy cows in the United States. However, the long growing season of corn may prevent double cropping with a winter annual such as triticale in some areas that have shorter growing seasons.

Pearl millet is a warm-season annual grass that has a shorter growing season than corn (65 d vs. 130 d, respectively) and may be more practical for double cropping strategies in certain northern geographic regions and years (e.g., abnormally wet spring seasons that delay corn planting). Additionally, pearl millet is drought tolerant and has a high water use efficiency which is a particularly important trait for crops planted after winter annual cereals (cover crops) that may decrease the available soil moisture (Maman et al., 2003; ZegadaLizarazu and Iijima, 2005). Furthermore, inclusion of pearl millet in a cropping plan may reduce corn disease pressure by rotating away from continuous corn every few years (Thomison et al., 2011). To support high milk production of lactating dairy cows, the harvested for- 
age must be highly digestible (Van Soest, 1994). There is a brown midrib (BMR) phenotype with lower lignin content and increased digestibility in certain pearl millet varieties (Cherney et al., 1990; Mustafa et al., 2004; Hassanat et al., 2007).

Messman et al. (1992) reported that milk yield (MY) of mid-lactation dairy cows was maintained when pearl millet replaced corn silage in the diet. In another study with lactating cows, MY was unaffected but yield of ECM was increased by feeding pearl millet silage at $35 \%$ of the diet DM instead of corn silage (Amer and Mustafa, 2010). On the other hand, in an experiment by Brunette et al. (2014), MY responses to 2 pearl millet cultivars were inconsistent; feeding regular pearl millet silage decreased MY, but feeding sweet pearl millet silage did not affect MY when both were compared with corn silage. A more recent study by Brunette et al. (2016) compared grass silage with either pearl millet silage harvested in either the vegetative or mature stage. They reported no differences in MY between the grass and pearl millet silage harvested in the vegetative stage, but they did see a decrease in MY by the pearl millet harvested at the mature stage. To the authors' knowledge, no studies have investigated feeding BMR pearl millet to lactating cows.

Therefore, the hypothesis of this study was that BMR brachytic dwarf pearl millet silage could serve as alternative forage to partially substitute corn silage in lactating dairy cow rations in the northeastern United States. The objective of the experiment was to partially replace corn silage with BMR dwarf pearl millet silage at $10 \%$ of the diet DM and investigate the effects on DMI, MY, milk components and fatty acid (FA) profile, nutrient digestibility, $\mathrm{N}$ utilization, and enteric methane $\left(\mathrm{CH}_{4}\right)$ emissions in lactating dairy cows.

\section{MATERIALS AND METHODS}

\section{Crops and Silages}

The forages were grown in Centre County, Pennsylvania, at approximately $40^{\circ} \mathrm{N}$ latitude on Hagerstown soil. Brown midrib dwarf pearl millet (Pennisetum glaucum 'Exceed'; King's Agriseeds, Ronks, PA) was planted on June 15, 2016, with a no-till drill (John Deere 1590; Moline, IL) at a seeding rate of $22.4 \mathrm{~kg} /$ ha and a 19-cm row spacing. The field was sprayed with glyphosate and fertilized with $44.8 \mathrm{t} / \mathrm{ha}$ of dairy manure contributing $42 \mathrm{~kg} / \mathrm{ha}$ of ammonium $\mathrm{N}$ and 177 $\mathrm{kg} / \mathrm{ha}$ of organic N. An additional $73 \mathrm{~kg}$ of N/ha from a 30\% urea and ammonium nitrate liquid fertilizer was applied before planting. Soybeans were grown in the field the previous year. A John Deere 945 mower with a flail conditioner was used to mow the crop on August 3,2016 , at the flag leaf visible stage at a height of $11.5 \mathrm{~cm}$. After wilting to a target $30 \% \mathrm{DM}$, the forage was gathered and chopped using a John Deere 6750 harvester on August 5, 2016. Chop length was set to $25 \mathrm{~mm}$. The millet was ensiled without inoculant in a 2.4-m-diameter plastic silage bag (Up North Plastics, Cottage Grove, MN).

The silage corn (DKC 52-61; 102-d relative maturity; DeKalb, St. Louis, MO) was not specifically grown for the current experiment but was from the forage source normally fed to the dairy herd at The Pennsylvania State University. The corn for silage was planted between May 1 and May 10, 2015, at a rate of 79,000 seeds/ha. It was planted with a no-till drill (John Deere 1590) into fields fertilized with dairy manure as stated above. An additional $43 \mathrm{~kg} / \mathrm{ha}$ of $\mathrm{N}$ was applied as $30 \%$ urea and ammonium nitrate liquid before planting and $67 \mathrm{~kg} / \mathrm{ha}$ of $\mathrm{N}$ in the same form as a side-dress application. Corn silage harvest was conducted between September 24 and September 28, 2015, at a target DM of $38 \%$ with a $19-\mathrm{mm}$ chop length and ensiled in an upright concrete silo.

\section{Animals and Diets}

All animals were cared for according to procedures approved by The Pennsylvania State University's Institutional Animal Care and Use Committee. Seventeen mid-lactation Holstein dairy cows $(\mathrm{MY}=50 \pm 4.2 \mathrm{~kg}$; $2.5 \pm 0.62$ lactations; DIM $=66 \pm 20 \mathrm{~d} ; \mathrm{BW}=630 \pm$ $71 \mathrm{~kg}$ at the beginning of the experiment) were used in the feeding experiment, and an additional 4 cows were used in the in situ analysis. The experiment was a crossover design with 2 periods of $28 \mathrm{~d}$ each; $21 \mathrm{~d}$ were allowed for adaptation to the diet, and the last 7 $\mathrm{d}$ of each period were for data and sample collection. Cows were allocated to 8 groups of 2 cows each, plus 1 spare cow, based on DIM, MY, and parity. One cow got mastitis at the end of the first sampling period. Therefore, we decided to also collect samples from the spare cow for the second period. Cows within a group were randomly assigned to 1 of 2 diets as described below. All cows were housed in the tiestall barn of The Pennsylvania State University's Dairy Research and Teaching Center. Diets were mixed and fed from a Rissler model 1050 TMR mixer (I. H. Rissler Manufacturing LLC, Mohnton, PA). Cows were fed once daily around 8 a.m. to yield approximately 5 to $10 \%$ refusals. Feed was pushed up 3 times throughout the day. The cows were milked twice daily at 7 a.m. and 6 p.m.

Two different diets (Table 1) were fed to the cows during the experiment: a control diet (CSD), based on 
Table 1. Ingredient and chemical composition of the diets ${ }^{1}$ fed in the experiment

\begin{tabular}{|c|c|c|}
\hline Item & CSD & PMD \\
\hline \multicolumn{3}{|l|}{ Ingredient, $\%$ of DM } \\
\hline Corn silage & 50 & 40 \\
\hline Pearl millet silage & - & 10 \\
\hline Alfalfa haylage $^{2}$ & 6 & 6 \\
\hline Hay-straw mixture & 4 & 4 \\
\hline Cottonseed hulls & 2 & 2 \\
\hline Ground corn & 10 & 10 \\
\hline Heat-treated whole soybeans & 5.5 & 5.5 \\
\hline Solvent-extracted canola meal & 9 & 9 \\
\hline SoyPLUS $^{3}$ & 7.5 & 7.5 \\
\hline Molasses $^{4}$ & 4 & 4 \\
\hline Mineral-vitamin premix ${ }^{5}$ & 2 & 2 \\
\hline \multicolumn{3}{|l|}{ Composition, ${ }^{6} \%$ of DM } \\
\hline $\mathrm{CP}$ & 16.6 & 17.2 \\
\hline $\mathrm{RDP}^{7}$ & 9.1 & 9.2 \\
\hline RUP $^{7}$ & 7.5 & 7.9 \\
\hline NDF & 30.3 & 32.4 \\
\hline $\mathrm{ADF}$ & 19.3 & 20.5 \\
\hline NFC & 43.9 & 40.2 \\
\hline Starch & 28.0 & 24.1 \\
\hline Fat & 4.6 & 4.6 \\
\hline $\mathrm{NE}_{\mathrm{L}}, \mathrm{Mcal} / \mathrm{kg}$ & 1.53 & 1.54 \\
\hline $\mathrm{NE}_{\mathrm{L}}$ intake, Mcal/d & 44.6 & 44.6 \\
\hline $\mathrm{NE}_{\mathrm{L}}$ balance, $\mathrm{Mcal} / \mathrm{d}$ & -0.7 & -0.5 \\
\hline MP balance, $\mathrm{g} / \mathrm{d}$ & 163 & 322 \\
\hline Ash & 6.77 & 7.67 \\
\hline $\mathrm{Ca}$ & 0.8 & 0.8 \\
\hline $\mathrm{P}$ & 0.4 & 0.4 \\
\hline $\mathrm{DCAD}, \mathrm{mEq} / \mathrm{kg}$ & 204 & 288 \\
\hline
\end{tabular}

${ }^{1} \mathrm{CSD}=$ corn silage control diet; PMD $=$ pearl millet silage diet.

${ }^{2}$ Alfalfa haylage was $34.8 \% \mathrm{DM}$ and contained (DM basis) $22.1 \% \mathrm{CP}$, $24.4 \% \mathrm{NFC}$, and $42.2 \% \mathrm{NDF}$.

${ }^{3}$ Manufactured by West Central Cooperative (Ralston, IA).

${ }^{4}$ Manufactured by Westway Feed Products (Tomball, TX).

${ }^{5}$ Manufactured by Cargill Animal Nutrition (Roaring Spring, PA). Contained (\%, as-is basis) limestone, 36.75; dry corn distillers grains with solubles, 29.00; NaCl, 24.85; $\mathrm{MgO}(54 \% \mathrm{Mg})$, 4.15; Bio-Phos (PCS Sales USA Inc., Chicago, IL), 2.45; zinc sulfate, 0.96; mineral oil, 0.5 ; vitamin E, 0.37; manganese sulfate, 0.37; copper sulfate, 0.26 ; ferrous sulfate, 0.16 ; selenium, 0.13 ; vitamin $\mathrm{A}, 0.03$; vitamin $\mathrm{D}_{3}, 0.013$; calcium iodate, 0.008; cobalt carbonate, 0.005 .

${ }^{6}$ Values of $\mathrm{CP}, \mathrm{NDF}, \mathrm{ADF}$, starch, fat, ash, Ca, and $\mathrm{P}$ were calculated using the chemical analysis (Cumberland Valley Analytical Services Inc., Maugansville, MD) of individual feed ingredients of the diet. Values of $\mathrm{NFC}, \mathrm{NE}_{\mathrm{L}}, \mathrm{NE}_{\mathrm{L}}$ intake, $\mathrm{NE}_{\mathrm{L}}$ balance, and $\mathrm{MP}$ balance were estimated based on NRC (2001).

${ }^{7}$ Estimated based on NRC (2001).

corn silage and alfalfa haylage, or a pearl millet silage $\operatorname{diet}(\mathbf{P M D})$, in which pearl millet silage was included at $10 \%$ of dietary DM, replacing $20 \%$ of the control diet corn silage DM. Thus, the only difference between CSD and PMD was the replacement of $20 \%$ of the corn silage DM with pearl millet silage to mimic a possible proportion of whole-farm pearl millet crop yield. The CSD diet was formulated to meet or exceed the NRC (2001) $\mathrm{NE}_{\mathrm{L}}$ and $\mathrm{MP}$ requirements of a Holstein cow with a BW of $630 \mathrm{~kg}$, an MY of $48 \mathrm{~kg}, 3.8 \%$ fat, $2.95 \%$ true protein, and a DMI of $28 \mathrm{~kg}$.

\section{Sampling and Analyses}

Refusals, TMR, and Feed Ingredients. Refusals were collected into a Ranger Mate mobile tub scale (American Calan, Northwood, $\mathrm{NH}$ ) and weighed individually for each cow before the morning feeding to measure daily as-fed intake. Total mixed ration, refusal, and forage (pearl millet, alfalfa, and corn silage) samples were collected twice weekly, composited by week and diet (i.e., silage type), and stored at $-20^{\circ} \mathrm{C}$. The TMR was sampled within $1 \mathrm{~h}$ of feeding. The weekly DM content of the TMR and refusals, oven dried at $55^{\circ} \mathrm{C}$ for $72 \mathrm{~h}$, was used to calculate the individual daily DMI. Fermentation profiles of fresh frozen samples of the pearl millet, alfalfa, and corn silages from each period were analyzed by Cumberland Valley Analytical Services Inc. (Maugansville, MD) by wet chemistry for $\mathrm{pH}$ and lactic, acetic, propionic, butyric, and isobutyric acid concentrations. Pearl millet, corn, and alfalfa silages were oven dried at $55^{\circ} \mathrm{C}$ for $72 \mathrm{~h}$, ground through a 4-mm screen (for in situ degradability measurements), and then ground through a 1-mm screen in a Wiley mill (Thomas Scientific, Swedesboro, NJ) and composited by period on an equal-weight basis. Dried composite samples of pearl millet, alfalfa, and corn silages were sent to Cumberland Valley Analytical Services Inc. to be analyzed by wet chemistry methods for amylasetreated NDF (Van Soest et al., 1991), ADF (method 973.18; AOAC International, 2000), lignin (Goering and Van Soest, 1970), fat (method 2003.05; AOAC International, 2006), CP (method 990.03; AOAC International, 2000), soluble protein (Krishnamoorthy et al., 1982), starch (Hall, 2009), ethanol-soluble carbohydrates (which measure mono-, di-, and oligosaccharides; DuBois et al., 1956), ash (method 942.05; AOAC International, 2000), and minerals (method 985.01; AOAC International, 2000).

Concentrate feeds were sampled weekly and stored at $-20^{\circ} \mathrm{C}$ until analysis. Concentrate feed samples were ground and composited once for the entire experiment. Dried composite concentrate ingredients were analyzed by Cumberland Valley Analytical Services Inc. by wet chemistry methods for CP, amylase-treated NDF, $\mathrm{ADF}$, fat, $\mathrm{CP}$, starch, ash, and minerals (procedures as referenced above). The percentage NFC was calculated using the equation NFC $\%=100-\mathrm{CP} \%$ - fat $\%-$ $\mathrm{NDF} \%$ - ash $\%$, and $\mathrm{NE}_{\mathrm{L}}$ was calculated using the equation $\mathrm{NE}_{\mathrm{L}}=0.0245 \times \mathrm{TDN}-0.12$. Concentrations of $\mathrm{CP}, \mathrm{NDF}, \mathrm{ADF}, \mathrm{NFC}, \mathrm{NE}_{\mathrm{L}}$, starch, fat, ash, $\mathrm{Ca}$, and $\mathrm{P}$ in the TMR were calculated based on the individual feed ingredient values and their percentage inclusion in the TMR. The diet values for RDP, RUP, and $\mathrm{NE}_{\mathrm{L}}$ balance were calculated based on NRC (2001) at actual DMI, MY, BW, and milk composition of the cows. 
Milk. Milk weights were automatically recorded at each milking using the Afimilk system (Kibbutz Afikim, Israel). Milk samples for components and FA analysis were collected on 2 consecutive days (4 consecutive milkings) during wk 4 of each experimental period from the p.m. and a.m. milkings. Milk component samples were collected into tubes containing 2-bromo-2-nitropropane-1,3-diol and analyzed individually by Dairy One Laboratory (Ithaca, NY) for fat, true protein, MUN, and lactose content using infrared spectroscopy (Milkoscan 4000; Foss Electric, Hillerød, Denmark). Milk samples for FA analysis from the 4 milkings for each period were collected without preservative, stored chilled at $4^{\circ} \mathrm{C}$, and later composited by cow weighted for the milk production of each milking. The composited milk samples were centrifuged (15 min, at $\left.4^{\circ} \mathrm{C}, 16,000 \times \mathrm{g}\right)$ and the milk fat was skimmed off and then stored frozen at $-20^{\circ} \mathrm{C}$ until analyzed for FA using the procedure described by Rico and Harvatine (2013). Cow BW was recorded twice daily upon exiting the milking parlor using an AfiFarm 3.04E scale system (S.A.E. Afikim, Rehovot, Israel).

Estimation of Digestibility and Gas Emissions. During wk 4 of each period, urine and fecal samples were collected for estimation of apparent digestibility and $\mathrm{N}$ utilization. To obtain a representative sample of a $24-\mathrm{h}$ period, spot urine and fecal samples (approximately $300 \mathrm{~mL}$ and $500 \mathrm{~g} /$ sample, respectively) were collected 8 times over $3 \mathrm{~d}$ at (d 1) 0500, 1100, 1700, and 2300 h; (d 2) 0800, 1400, and 2000 h; and (d 3) 0200. A full description of the urine and fecal sample processing and analyses can be found in Lee et al. (2012). Briefly, raw urine from each sampling was acidified, diluted, composited by cow and period, and stored frozen at $-20^{\circ} \mathrm{C}$ for later analysis of allantoin, uric acid, creatinine, urea $\mathrm{N}$, and total N. Allantoin was analyzed following the procedure by Chen et al. (1992). Stanbio Laboratory (Boerne, TX) kits were used to analyze uric acid (uric acid kit 1045), creatinine (creatinine kit 420), and urea $\mathrm{N}$ (urea nitrogen kit 580). Total $\mathrm{N}$ was analyzed in freeze-dried urine samples of approximately $60 \mu \mathrm{L}$ of 1:10 diluted and acidified urine using a Costech ECS $4010 \mathrm{C} / \mathrm{N} / \mathrm{S}$ elemental analyzer (Costech Analytical Technologies Inc., Valencia, CA). Fecal samples were oven dried at $65^{\circ} \mathrm{C}$, ground through a $1-\mathrm{mm}$ screen in a Wiley mill (Arthur H. Thomas Co., Swedesboro, $\mathrm{NJ}$ ), and analyzed for DM, OM, CP, starch, NDF, and ADF. A Mixer Mill MM 200 (Retsch GmbH, Haan, Germany) was used to pulverize a 0.5 -g aliquot of fecal sample for $\mathrm{CP}$ analysis $(\mathrm{N} \times 6.25)$ using a Costech ECS 4010 C/N/S elemental analyzer. Starch analysis of fecal DM for apparent total-tract digestibility was performed using a procedure similar to the method including acetate buffer described by Hall (2009). Briefly, starch was gelatinized with $50 \% \mathrm{NaOH}$, incubated for $16 \mathrm{~h}$ at $55^{\circ} \mathrm{C}$ with acetate buffer and amylase, centrifuged, plated on a 96-well plate, and then reacted with a glucose-oxidase-peroxidase enzyme solution (P7119; Sigma-Aldrich, St. Louis, MO) for 45 min before being read at $450 \mathrm{~nm}$. The NDF and ADF were analyzed with an Ankom 200 fiber analyzer (Ankom Technology Corp., Macedon, NY) based on the procedures of Van Soest et al. (1991) with $\alpha$-amylase and sodium sulfite in the NDF analysis. A 12-d ruminal incubation was used to analyze indigestible NDF (Huhtanen et al., 1994, as modified by Lee et al., 2012) in both feces and TMR, which was used as a marker to estimate apparent totaltract digestibilities of dietary nutrients.

Enteric $\mathrm{CH}_{4}$ and carbon dioxide $\left(\mathrm{CO}_{2}\right)$ emissions were measured during wk 4 of each experimental period with the GreenFeed system (C-Lock Inc., Rapid City, $\mathrm{SD})$. The GreenFeed system measures gas mass fluxes and is one of the established techniques for measuring enteric $\mathrm{CH}_{4}$ emissions from ruminant animals (Hristov et al., 2015b; Hammond et al., 2016). One GreenFeed unit was used to measure gas emissions from all cows individually in a sequential manner for $5 \mathrm{~min}$ of breath gas sampling and 2 min of background gas sampling at every collection time point. There were 8 collection time points for each cow during each experimental period. To obtain a representative sample of a $24-\mathrm{h}$ period, the unit was positioned in the feed bunk in front of each cow starting at (d 1) 0800, 1400, and $2000 \mathrm{~h}$; (d 2) 0200, 1100, 1700, and $2300 \mathrm{~h}$; and (d 3) $0500 \mathrm{~h}$. A detailed and visual explanation of the gas sampling procedures can be viewed in Hristov et al. (2015a). Gas emission data were averaged by cow and period for the statistical analysis.

\section{In Situ DM and NDF Degradation}

Ruminal disappearance of DM and NDF was determined in situ for pearl millet, alfalfa, and corn silages that were fed during the experiment. Four ruminally cannulated lactating Holstein cows averaging DMI of $28.3 \pm 4.9 \mathrm{~kg}$, MY of $37.8 \pm 9.2 \mathrm{~kg}, 2.8 \pm 0.5$ lactations; $208 \pm 26 \mathrm{DIM}$, and $639 \pm 94.4 \mathrm{~kg}$ of BW were used for in situ incubations. Cows were fed the following on a DM basis: corn silage, $51.3 \%$; alfalfa haylage, 7.4\%; straw, 3.5\%; canola meal, 8.9\%; SoyPlus (West Central Cooperative, Ralston, IA), $8.0 \%$; ground corn, $7.0 \%$; roasted soybeans, $5.0 \%$; molasses, $5.0 \%$; whole cotton seed, $2 \%$; and mineral mix, $1.9 \%$. The in situ procedure was performed as described in Harper et al. (2017b). Briefly, triplicate samples of $7 \mathrm{~g}$ each of dried 4-mm ground silages were weighed into Ankom nylon bags $(10 \mathrm{~cm} \times 20 \mathrm{~cm}$ forage bag; Ankom Technology Corp., Macedon, NY), which were sequentially incu- 
bated in the ventral rumen for $96,72,48,24,12$, and $0 \mathrm{~h}$ and simultaneously removed. All bags were washed under cold water and then oven dried for $72 \mathrm{~h}$ at $55^{\circ} \mathrm{C}$. Ruminal disappearance was calculated based on initial dry weight of the incubated sample, residue dry weight, and NDF concentration of the initial sample and bag residue. Degradation data were fitted to a line rising exponentially to a maximum value with the equation $p$ $=a+b\left(1-\mathrm{e}^{-c t}\right)$ using SigmaPlot v. 10.0 (Systat Software Inc., San Jose, CA), where $p$ is the degraded fraction (of DM or NDF) at time $t$, constant $a$ is the soluble fraction (or intercept), $b$ is the potentially degradable fraction (i.e., predicted fraction of DM or NDF that is potentially degradable in the rumen), and $c$ is the rate of degradation of the $b$ fraction (Ørskov and McDonald, 1979). The effective degradability (ED; an estimate of the percentage of DM or NDF that would be degraded in the rumen at specified passage rate) was determined with the following equation (Ørskov and McDonald, 1979): $\mathrm{ED}=a+b[c /(c+k)]$, where $k$ is the rate of passage assumed to be $3 \% / \mathrm{h}$.

\section{Statistical Analysis}

Statistical analyses were run using the MIXED procedure of SAS v. 9.4 (SAS Institute Inc., Cary, NC). Cow was the experimental unit. Milk yield, BW, and DMI from the last $7 \mathrm{~d}$ of the experiment and the $2 \mathrm{~d}$ of milk composition samples were analyzed with day as a repeated measure using an $\mathrm{AR}(1)$ covariance structure. The statistical model included diet, day, period, and period $\times$ diet and diet $\times$ day interactions. Group and cow within group were random effects, and all others were fixed. Milk FA, nutrient intake, apparent digestibility, $\mathrm{N}$ utilization, and $\mathrm{CH}_{4}$ and $\mathrm{CO}_{2}$ emissions data were analyzed using the same model without day and diet $x$ day interaction. Body weight change was calculated as the average $\mathrm{BW}$ of the last $3 \mathrm{~d}$ of the experimental period less the average BW of the first $3 \mathrm{~d}$ of the experimental period. Milk composition data were weighted averages per day based on the MY of the evening and morning milkings. Individual ruminal in situ degradation parameters $(a, b, c$, and $\mathrm{ED})$ of $\mathrm{DM}$ and NDF were contrasted among forages. For all data, significance was declared at $P \leq 0.05$ and tendency was declared at $0.05<P \leq 0.10$. Data are presented as least squares means unless indicated otherwise.

\section{RESULTS AND DISCUSSION}

\section{Forages}

Brown midrib dwarf pearl millet yielded $2.8 \mathrm{t}$ of $\mathrm{DM} /$ ha in the first cutting and was used to conduct the animal experiment. Nutrient composition and fermentation profiles of pearl millet and corn silages are shown in Table 2. The corn silage had a high starch content of $40 \% \mathrm{DM}$ in contrast to the $<1 \%$ starch in the pearl millet silage. The pearl millet was harvested at the flag leaf visible stage and, therefore, low starch concentrations were expected. Pearl millet silage had a higher concentration of NDF compared with corn silage, which was similar to results of Hassanat et al. (2007) and Mustafa et al. (2004), who reported 59 and $61 \%$ NDF, respectively, in BMR pearl millet forage. Lignin concentration was similar between pearl millet silage and corn silage. Lignin is found in the plant cell wall, and its association with cellulose and hemicellulose decreases NDF digestibility (Van Soest, 1994). Therefore, a better way to compare lignin concentrations between the corn and pearl millet silages may be on an NDF basis. Looking at lignin this way shows a larger difference between the forages at 7.42 versus $4.28 \%$ lignin, as a percentage of NDF, for corn silage and pearl millet silage, respectively. Crude protein content was greater in the pearl millet silage compared with the corn silage. Potassium concentration was greater in the pearl millet silage, which would be a disadvantage when trying to lower diet DCAD in prepartum cows to decrease the risk of hypocalcemia (Charbonneau et al., 2006).

Table 2. Nutrient composition and fermentation profile of pearl millet and corn silages ${ }^{1}$ (\% of DM or as indicated)

\begin{tabular}{lrr}
\hline Item & Corn & Pearl millet \\
\hline Nutrient composition & & \\
DM, \% & $42.2 \pm 1.6$ & $30.5 \pm 0.8$ \\
NDF & $36.8 \pm 0.4$ & $58.4 \pm 0.1$ \\
ADF & $22.3 \pm 0.6$ & $34.4 \pm 0.8$ \\
Lignin & $2.73 \pm 0.2$ & $2.50 \pm 0.1$ \\
Lignin, \% of NDF & $7.42 \pm 0.4$ & $4.28 \pm 0.1$ \\
Fat (ether extract) & $2.58 \pm 0.2$ & $3.31 \pm 0.0$ \\
CP & $7.45 \pm 0.6$ & $13.2 \pm 0.2$ \\
Soluble CP, \% of CP & $61.2 \pm 0.4$ & $63.7 \pm 0.1$ \\
$\mathrm{NH}_{3}$ CP equivalent & $0.88 \pm 0.1$ & $1.94 \pm 0.2$ \\
NH CP equivalent, \% of CP $_{\text {Starch }}^{11.8 \pm 0.2}$ & $14.6 \pm 1.6$ \\
Ethanol soluble carbohydrates & $40 \pm 1.9$ & $0.9 \pm 0.3$ \\
Ash & $1.3 \pm 0.2$ & $1.95 \pm 0.8$ \\
Ca & $3.8 \pm 0.1$ & $12.9 \pm 0.1$ \\
P & $0.29 \pm 0.0$ & $0.96 \pm 0.2$ \\
K & $0.23 \pm 0.0$ & $0.32 \pm 0.0$ \\
pH & $1.05 \pm 0.1$ & $5.13 \pm 0.1$ \\
Fermentation acids & 2 \\
Lactic & $3.79 \pm 0.1$ & $4.48 \pm 0.1$ \\
Acetic & & \\
Propionic & $5.90 \pm 0.6$ & $6.25 \pm 0.2$ \\
\hline
\end{tabular}

${ }^{1}$ Two composite samples per silage ( 1 for each experimental period) were analyzed by wet chemistry (Cumberland Valley Analytical Services Inc., Maugansville, MD). Mean $\pm \mathrm{SE}$ is reported.

${ }^{2}$ Butyric and isobutyric acids were not detected in either silage.

${ }^{3} \mathrm{ND}=$ not detected. 
Fermentation acid concentrations were numerically similar between the forages. Butyric acid was not detected in either silage, indicating that clostridial fermentation was likely not taking place. Silage $\mathrm{pH}$ was considerably lower for corn silage compared with the pearl millet silage, which had a $\mathrm{pH}$ typical for grass silages. Ward et al. (2001) reported a similar $\mathrm{pH}$ of 4.50 for pearl millet silage in their study.

\section{$D M I, B W$, and $M Y$}

Dry matter intake, BW, and milk production results are shown in Table 3. Diet had no effect on DMI. Dry matter intake is driven by nutrient demand (e.g., ECM yield) and constrained by rumen capacity (Mertens, 2009). Messman et al. (1992) reported a decrease in DMI for a diet containing $50 \%$ non-BMR pearl millet containing $46.5 \%$ NDF compared with an alfalfa and corn silage control diet containing $35.0 \% \mathrm{NDF}$. The current study PMD treatment contained 32.4\% NDF and does not seem to have restricted DMI. Body weight change was not statistically different, but the shortterm ( $28 \mathrm{~d})$ design of this study did not enable us to statistically perceive small differences in BW change. Yield of ECM and ECM feed efficiency were similar between CSD and PMD. Amer and Mustafa (2010) likewise reported no change in DMI for lactating cows fed pearl millet silage or corn silage at approximately $35 \%$ of the diet, nor did they see a reduction in MY (averaging $38 \mathrm{~kg} / \mathrm{d}$ ) or feed efficiency (1.60 kg of milk/ $\mathrm{kg}$ of DMI). Unfortunately, specific effects of pearl millet on milk production are difficult to elucidate in that study because Megalac (Church \& Dwight, Princeton, NJ), a calcium salt product of palm oil FA, was supplemented uniquely to the pearl millet diet and likely influenced the results. The design of the current study altered only the amount of corn silage and pearl millet in the diet, and therefore differences in the data between treatments can be directly attributed to the forage change. Milk yield of the current study was decreased $(P<0.001)$ by PMD along with a decrease in feed efficiency per unit of milk $(P<0.01)$. However, as the next section details, MY differences were largely based on a lower concentration of milk components in CSD milk, which does not add value to milk producers and therefore should not be emphasized.

\section{Milk Composition and Yield}

Milk fat content tended to increase $(P=0.06)$ from $3.47 \%$ with CSD to $3.71 \%$ with PMD, but milk fat yield was not different between diets. Milk true protein content and yield were similar between diets. Lactose content and yield were also not different between diets. Early research reported decreases in milk fat content of dairy cows grazing pearl millet (Miller et al., 1965; Bucholtz et al., 1969) and consuming pearl millet greenchop (Harner et al., 1969; Schneider et al., 1970) versus sudan grass. More recent research from Messman et al. (1992) and Brunette et al. (2014) observed numerically increased milk fat content when comparing corn silage with pearl millet silage. Furthermore, increases in milk

Table 3. Effect of pearl millet silage on DMI, milk production, and feed efficiency in lactating dairy cows

\begin{tabular}{|c|c|c|c|c|}
\hline \multirow[b]{2}{*}{ Item } & \multicolumn{2}{|c|}{ Diet $^{1}$} & \multirow[b]{2}{*}{$\mathrm{SEM}^{2}$} & \multirow[b]{2}{*}{ Diet $P$-value } \\
\hline & CSD & PMD & & \\
\hline DMI, $\mathrm{kg} / \mathrm{d}$ & 29.1 & 29.0 & 0.65 & 0.78 \\
\hline Milk yield, $\mathrm{kg} / \mathrm{d}$ & 51.3 & 49.6 & 2.02 & $<0.001$ \\
\hline Milk/DMI, $\mathrm{kg} / \mathrm{kg}$ & 1.77 & 1.72 & 0.053 & 0.01 \\
\hline Milk fat, $\%$ & 3.47 & 3.71 & 0.118 & 0.06 \\
\hline Milk fat, $\mathrm{kg} / \mathrm{d}$ & 1.79 & 1.82 & 0.087 & 0.65 \\
\hline Milk true protein, \% & 2.86 & 2.85 & 0.050 & 0.64 \\
\hline Milk true protein, $\mathrm{kg} / \mathrm{d}$ & 1.46 & 1.43 & 0.055 & 0.44 \\
\hline Lactose, $\%$ & 5.00 & 4.96 & 0.035 & 0.28 \\
\hline Lactose, $\mathrm{kg} / \mathrm{d}$ & 2.55 & 2.47 & 0.116 & 0.23 \\
\hline MUN, $\mathrm{mg} / \mathrm{dL}$ & 11.6 & 13.3 & 0.410 & $<0.001$ \\
\hline $\mathrm{ECM}^{3}{ }^{3} \mathrm{~kg} / \mathrm{d}$ & 46.8 & 46.6 & 1.92 & 0.86 \\
\hline ECM/DMI, kg/kg & 1.59 & 1.56 & 0.050 & 0.50 \\
\hline $\mathrm{BW}, \mathrm{kg}$ & 632 & 628 & 16.8 & 0.01 \\
\hline BW change, kg & 7.23 & 5.27 & 3.335 & 0.72 \\
\hline
\end{tabular}

${ }^{1} \mathrm{CSD}=$ corn silage control diet; PMD $=$ pearl millet silage diet.

${ }^{2}$ Largest SEM published in table. DMI, $\mathrm{n}=235$; milk yield, $\mathrm{n}=231$; milk yield/DMI, $\mathrm{n}=230$; $\mathrm{BW}, \mathrm{n}=$ 238; BW change, $\mathrm{n}=34$; milk composition data, $\mathrm{n}=65$ ( $\mathrm{n}$ represents the number of observations used in the statistical analysis).

${ }^{3}$ Calculated as $\mathrm{kg}$ of milk $\times[(38.3 \times \%$ fat $\times 10+24.2 \times \%$ true protein $\times 10+16.54 \times \%$ lactose $\times 10+$ 20.7)/3,140] (Sjaunja et al., 1990). 
Table 4. Effect of pearl millet silage on nutrient intake and apparent total-tract digestibility in lactating dairy cows

\begin{tabular}{lcccc}
\hline & \multicolumn{2}{c}{ Diet $^{1}$} & & \\
\cline { 2 - 3 } & & & \\
Item & CSD & PMD & & SEM \\
& & Diet $P$-value \\
\hline Intake, kg/d unless noted otherwise & & & & \\
DM $^{3}$ & 29.4 & 28.8 & 0.58 & 0.14 \\
OM & 27.4 & 26.6 & 0.54 & 0.03 \\
CP & 4.86 & 4.94 & 0.097 & 0.23 \\
Starch & 8.22 & 6.94 & 0.153 & $<0.001$ \\
NDF & 8.89 & 9.33 & 0.181 & 0.001 \\
NDF, \% of BW & 1.42 & 1.49 & 0.031 & 0.001 \\
Forage NDF, \% of BW & 1.11 & 1.19 & 0.025 & $<0.001$ \\
ADF & 5.67 & 5.90 & 0.115 & 0.004 \\
Apparent digestibility, \% & & & & \\
DM & 66.5 & 64.5 & 0.38 & $<0.001$ \\
OM & 67.2 & 65.1 & 0.38 & $<0.001$ \\
CP & 64.3 & 61.8 & 0.55 & 0.003 \\
Starch & 99.2 & 99.1 & 0.09 & 0.26 \\
NDF & 38.5 & 41.0 & 0.65 & $<0.001$ \\
ADF & 24.9 & 27.5 & 1.15 & 0.02 \\
\hline
\end{tabular}

${ }^{1} \mathrm{CSD}=$ corn silage control diet; PMD = pearl millet silage diet.

${ }^{2}$ Largest SEM published in table; $\mathrm{n}=33$ ( $\mathrm{n}$ represents the number of observations used in the statistical analysis).

${ }^{3}$ Intake of DM during the fecal collection periods.

fat concentration are often reported when total dietary fiber and fiber digestibility increase due to a shift in VFA production increasing the acetate:propionate ratio (Oba and Allen, 1999; Ivan et al., 2005). The PMD treatment had a higher NDF concentration, as stated earlier, and increased NDF digestibility, which is mentioned in the following section.

\section{Nutrient Intake and Digestibility}

Many of the production results discussed above relate to nutrient intake and apparent digestibility effects, presented in Table 4. Higher intakes of OM $(P=$ $0.03)$ and starch $(P<0.001)$ for CSD reflect the lower ash and higher starch concentrations, respectively, in the corn silage compared with pearl millet silage. The higher $\operatorname{NDF}(P=0.001)$ and $\operatorname{ADF}(P=0.004)$ intakes for PMD are a result of greater concentrations of those components in the pearl millet silage. Amer and Mustafa (2010) likewise reported higher NDF intake for lactating cows fed pearl millet silage versus corn silage. Greater $(P<0.001) \mathrm{DM}$ and $\mathrm{OM}$ apparent digestibility in CSD was a result of the more than $1 \mathrm{~kg} / \mathrm{d}$ higher starch intake and lower NDF intake in that diet compared with PMD. Apparent starch digestibility in this experiment was around 99\%, whereas NDF digestibility was approximately $40 \%$. There was a $>6 \%$ increase in $\mathrm{NDF}(P<0.001)$ and $\mathrm{ADF}(P=0.02)$ apparent digestibility for the PMD treatment. This is likely caused by 2 factors. First, cellulose digestion is decreased with lower rumen pH (Ørskov and Fraser, 1975) and, even though we did not measure rumen $\mathrm{pH}$ directly, it is likely that rumen $\mathrm{pH}$ was lower in cows fed CSD due to the higher starch content of CSD (Lechartier and Peyraud, 2011). Second, the pearl millet silage fiber components were likely more easily digestible due to less lignin per unit of NDF, indicating the potential for fewer lignin crosslinks with cellulose and hemicellulose in that early-harvested forage, as supported by the in situ data below (Mertens, 1985; Cherney et al., 1991; Grabber et al., 2009).

\section{Milk FA}

Milk FA data are shown in Table 5. The PMD treatment had higher $(P=0.04)$ concentrations of $4: 0$ and 6:0, but there were no differences in total de novo FA or SFA. There was a higher $(P=0.002)$ concentration of 18:0 in PMD and lower $(P \leq 0.02)$ concentration of total trans FA. Increased 18:0 in PMD indicates a more complete ruminal biohydrogenation of linoleic and linolenic UFA. This is supported by the decrease $(P=0.03)$ in total PUFA concentration (primarily 18 carbons) in PMD. Although total MUFA concentrations were not different between the treatments, trans-10 18:1 was higher $(P=0.008)$ in CSD. Increases in trans-10 18:1 have been negatively related to milk fat production primarily through its association with production of biohydrogenation intermediate trans-10, cis-12 CLA, which is its precursor (Harvatine et al., 2009; Rico and 
Table 5. Effect of pearl millet silage on milk fatty acid composition ( $\mathrm{g} / 100 \mathrm{~g}$ of total fatty acids) in lactating dairy cows

\begin{tabular}{|c|c|c|c|c|}
\hline \multirow[b]{2}{*}{ Fatty acid (FA) } & \multicolumn{2}{|c|}{ Diet $^{1}$} & \multirow[b]{2}{*}{ SEM $^{2}$} & \multirow[b]{2}{*}{ Diet $P$-value } \\
\hline & CSD & PMD & & \\
\hline $4: 0$ & 4.40 & 4.62 & 0.095 & 0.04 \\
\hline $6: 0$ & 2.39 & 2.51 & 0.045 & 0.04 \\
\hline $8: 0$ & 1.35 & 1.41 & 0.029 & 0.13 \\
\hline 10:0 & 3.22 & 3.24 & 0.084 & 0.73 \\
\hline cis-9 10:1 & 0.26 & 0.27 & 0.008 & 0.22 \\
\hline $11: 0$ & 0.08 & 0.07 & 0.007 & 0.02 \\
\hline $12: 0$ & 3.64 & 3.57 & 0.104 & 0.33 \\
\hline 13:0 iso & 0.003 & 0.006 & 0.002 & 0.22 \\
\hline 13:0 anteiso & 0.07 & 0.07 & 0.004 & 0.07 \\
\hline $13: 0$ & 0.13 & 0.11 & 0.008 & 0.01 \\
\hline 14:0 iso & 0.06 & 0.07 & 0.005 & $<0.001$ \\
\hline $14: 0$ & 11.4 & 11.1 & 0.168 & 0.11 \\
\hline 15:0 iso & 0.16 & 0.19 & 0.003 & $<0.001$ \\
\hline 15:0 anteiso & 0.33 & 0.35 & 0.006 & 0.005 \\
\hline cis-9 14:1 & 0.84 & 0.79 & 0.046 & 0.06 \\
\hline $15: 0$ & 1.06 & 0.99 & 0.046 & 0.12 \\
\hline 16:0 iso & 0.16 & 0.17 & 0.010 & 0.36 \\
\hline $16: 0$ & 26.8 & 26.5 & 0.526 & 0.48 \\
\hline 17:0 iso & 0.24 & 0.25 & 0.017 & 0.60 \\
\hline cis-9 16:1 & 1.12 & 1.06 & 0.074 & 0.08 \\
\hline 17:0 anteiso & 0.36 & 0.36 & 0.010 & 0.92 \\
\hline $17: 0$ & 0.47 & 0.47 & 0.010 & 0.92 \\
\hline cis-9 17:1 & 0.15 & 0.14 & 0.007 & 0.48 \\
\hline $18: 0$ & 11.0 & 11.8 & 0.428 & 0.002 \\
\hline trans-4 18:1 & 0.03 & 0.02 & 0.003 & 0.05 \\
\hline trans- 6,8 18:1 & 0.34 & 0.31 & 0.012 & 0.002 \\
\hline trans-9 18:1 & 0.27 & 0.25 & 0.008 & $<0.001$ \\
\hline trans-10 18:1 & 0.61 & 0.47 & 0.051 & 0.008 \\
\hline trans-11 18:1 & 1.16 & 1.10 & 0.056 & 0.27 \\
\hline trans-12 18:1 & 0.56 & 0.51 & 0.019 & 0.001 \\
\hline cis-9 18:1 & 17.4 & 17.5 & 0.349 & 0.79 \\
\hline trans-15 18:1 & 0.47 & 0.47 & 0.014 & 0.84 \\
\hline cis-11 18:1 & 0.94 & 0.82 & 0.042 & 0.001 \\
\hline cis-12 18:1 & 0.48 & 0.42 & 0.020 & $<0.001$ \\
\hline cis-9,12 18:2 & 3.14 & 3.06 & 0.087 & 0.04 \\
\hline cis-9,trans-11 18:2 & 0.51 & 0.45 & 0.028 & 0.06 \\
\hline cis- $6,9,1218: 3$ & 0.08 & 0.08 & 0.004 & 0.45 \\
\hline $20: 0$ & 0.12 & 0.13 & 0.003 & $<0.001$ \\
\hline cis-11 20:1 & 0.40 & 0.43 & 0.013 & 0.007 \\
\hline $22: 0$ & 0.04 & 0.05 & 0.003 & 0.006 \\
\hline $20: 3$ & 0.12 & 0.12 & 0.004 & 0.65 \\
\hline $20: 4$ & 0.15 & 0.15 & 0.006 & 0.18 \\
\hline$\Sigma$ de novo $\mathrm{FA}^{3}$ & 27.2 & 27.2 & 0.359 & 0.92 \\
\hline$\Sigma \mathrm{C} 16^{4}$ & 27.9 & 27.6 & 0.560 & 0.37 \\
\hline$\Sigma$ preformed $\mathrm{FA}^{5}$ & 37.8 & 38.1 & 0.678 & 0.62 \\
\hline$\Sigma \mathrm{SFA}$ & 67.4 & 68.1 & 0.605 & 0.25 \\
\hline$\Sigma$ MUFA & 25.0 & 24.5 & 0.480 & 0.32 \\
\hline$\Sigma$ PUFA & 4.00 & 3.86 & 0.112 & 0.03 \\
\hline$\sum$ trans $\mathrm{FA}^{6}$ & 3.95 & 3.57 & 0.153 & 0.02 \\
\hline$\Sigma \mathrm{OBCFA}^{7}$ & 3.26 & 3.25 & 0.072 & 0.77 \\
\hline Unknown & 3.58 & 3.58 & 0.064 & 0.95 \\
\hline
\end{tabular}

${ }^{1} \mathrm{CSD}=$ corn silage control diet; PMD = pearl millet silage diet.

${ }^{2}$ Largest SEM shown; $\mathrm{n}=33$ ( $\mathrm{n}$ represents number of observations used in the statistical analysis). Data are presented as LSM.

${ }^{3}$ Sum of fatty acids synthesized in the mammary gland (4:0, 6:0, 8:0, 10:0, 12:0, 14:0, 14:1).

${ }^{4}$ Sum of C16 fatty acids (16:0 and 16:1).

${ }^{5}$ Sum of $\mathrm{C} \geq 18$ fatty acids.

${ }^{6}$ Sum of trans UFA.

${ }^{7}$ Sum of the odd- and branched-chain fatty acids (11:0, iso 13:0, anteiso 13:0, 13:0, iso 14:0, iso 15:0, anteiso 15:0, 15:0, iso 16:0, iso 17:0, anteiso 17:0, 17:0, cis-9 17:1). 
Harvatine, 2013). Diets high in unsaturated fats, high in rapidly fermentable carbohydrates, and low in NDF tend to lower rumen $\mathrm{pH}$ and increase trans-10 18:1 production (Rico and Harvatine, 2013; Zened et al., 2013). Other studies have reported similar shifts in milk trans FA when comparing corn silage with grass silage diets (Nielsen et al., 2004; Shingfield et al., 2005).

The concentrations of branched-chain FA iso 14:0 and iso 15:0 were increased $(P<0.001)$ in PMD. Experiments replacing grass silage with corn silage, which is similar to the current study, have likewise reported a decrease in iso 14:0 and iso 15:0 in milk FA (Vlaeminck et al., 2006a). Cellulolytic bacteria Ruminococcus albus and Ruminococcus flavefaciens have higher concentrations of iso 14:0 and iso 15:0, respectively, than other rumen bacteria, particularly amylolytic species (Vlaeminck et al., 2006a). The PMD treatment in the current study would have promoted more favorable rumen conditions for cellulolytic bacteria than CSD. Additionally, Vlaeminck et al. (2006b) reported a positive correlation between iso 14:0 and iso 15:0 and rumen proportions of acetate and a negative correlation to rumen proportions of propionate, indicating potentially less propionate production by PMD.

\section{In Situ DM and NDF Degradation}

In situ DM (Figure 1) and NDF (Figure 2) disappearance data for the 3 silages fed in the experiment help characterize pearl millet silage. Dry matter solubility (i.e., fraction $a$ ) of pearl millet silage was lower $(P<0.001)$ than corn silage and alfalfa haylage $(21.5$ vs. 49.7 and $39.4 \%$, respectively; data not shown in tables). Potentially degradable DM, $b$ fraction, was highest $(P<0.001)$ in the pearl millet silage, $60.9 \%$, and similar for corn silage and alfalfa haylage (30.7 and $29.2 \%$, respectively). Fractional rate of disappearance of the potentially degradable DM, $c$, was highest ( $P$ $<0.001)$ for alfalfa haylage $(5.7 \% / \mathrm{h})$, lowest for corn silage $(2.1 \% / \mathrm{h})$, and intermediate for pearl millet silage $(3.1 \% / \mathrm{h})$. Effective degradability of DM, calculated with an estimated $3 \% / \mathrm{h}$ passage rate, was highest for

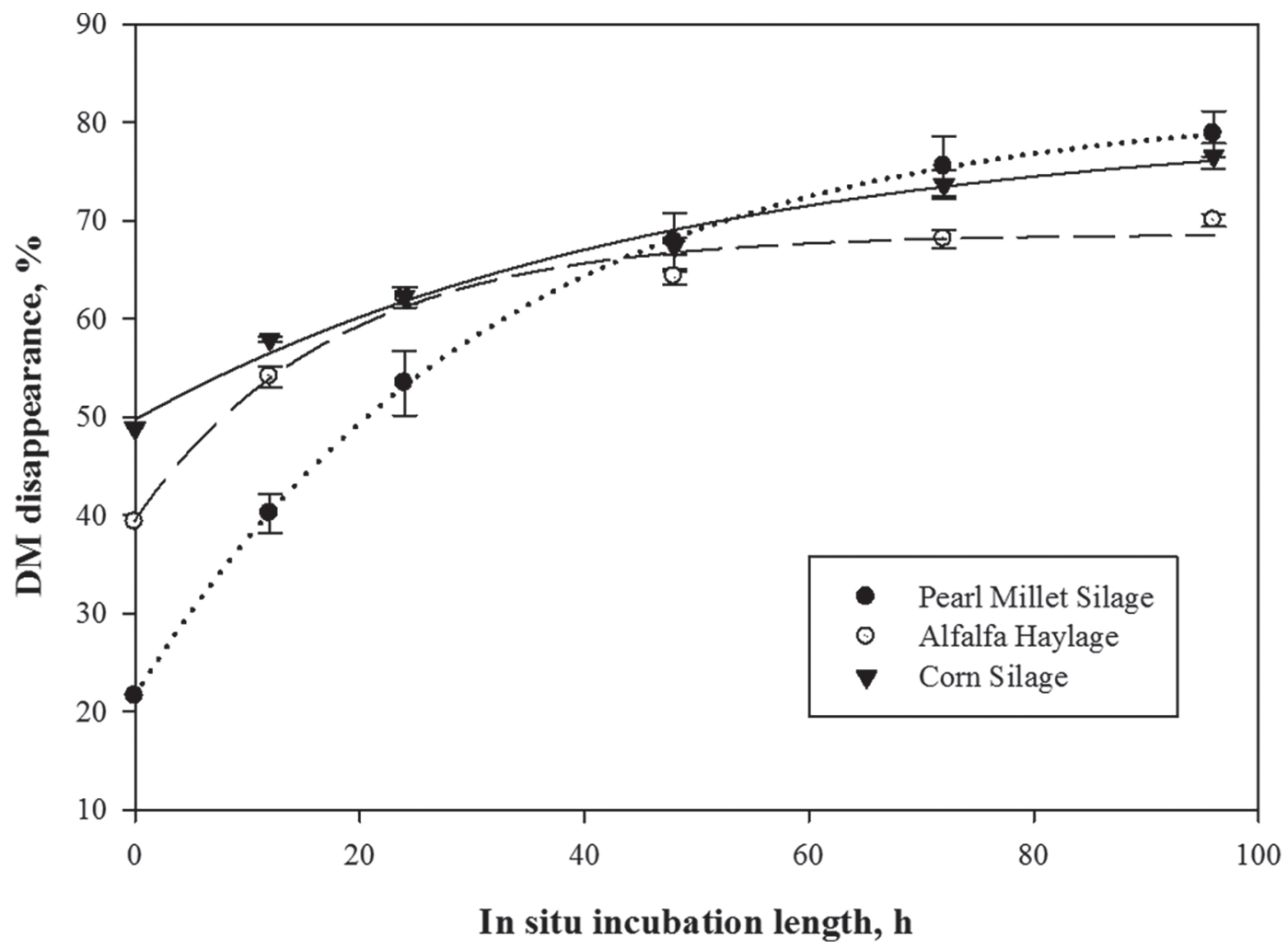

Figure 1. Ruminal in situ DM disappearance of forage sources. Data are means $\pm \mathrm{SE}(\mathrm{n}=4)$. Disappearance curves were fit using SigmaPlot 10.0 (Systat Software, Chicago, IL) to the equation $p=a+b\left(1-\mathrm{e}^{-c t}\right)$, where $p$ is the degraded fraction (of DM) at time $t, a$ is the soluble fraction, $b$ is the potentially degradable fraction, and $c$ is the rate of degradation of the $b$ fraction (Ørskov and McDonald, 1979). Effective degradability (ED) was estimated as $\mathrm{ED}=a+b[c /(c+k)]$, where $a, b$, and $c$ are as above and $k$ is the rate of passage (Ørskov and McDonald, 1979 ) assumed to be $3 \% / \mathrm{h}$ in this study. The ED values were as follows (model estimates $\pm \mathrm{SE}$ ): pearl millet silage, $52.2 \pm 2.23$; alfalfa haylage, $58.6 \pm 0.78$; corn silage, $62.3 \pm 0.50$. Values differed at $P<0.01$. 


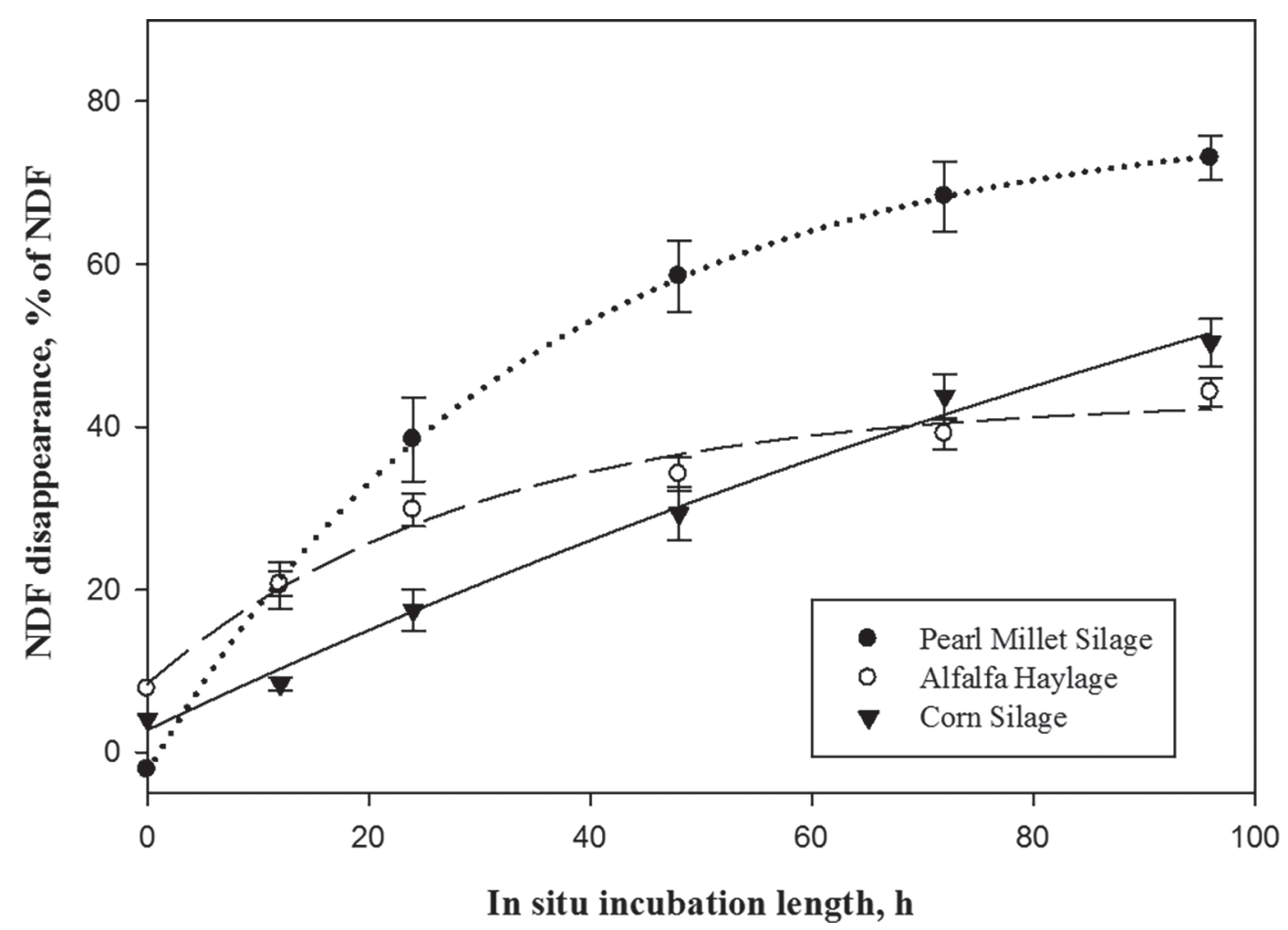

Figure 2. Ruminal in situ NDF disappearance of forage sources. Data are means $\pm \mathrm{SE}(\mathrm{n}=4)$. Disappearance curves of pearl millet silage, alfalfa haylage, and corn silage were fit using SigmaPlot 10.0 (Systat Software, Chicago, IL) to the equation $p=a+b\left(1-\mathrm{e}^{-c t}\right)$, where $p$ is the degraded fraction (of NDF) at time $t, a$ is the soluble fraction, $b$ is the potentially degradable fraction, and $c$ is the rate of degradation of the $b$ fraction (Ørskov and McDonald, 1979). Effective degradability (ED) was estimated as ED $=a+b[c /(c+k)]$, where $a, b$, and $c$ are as above and $k$ is the rate of passage (Ørskov and McDonald, 1979) assumed to be $3 \% / \mathrm{h}$ in this study. The ED values were as follows (model estimates $\pm \mathrm{SE}$ ): pearl millet silage, $37.3 \pm 3.17$; alfalfa haylage, $27.0 \pm 1.15$; corn silage, $21.9 \pm 1.40$. Values differed at $P<0.01$.

corn silage $(62.2 \%)$, intermediate for alfalfa haylage (58.6\%), and lowest for pearl millet silage $(52.2 \%$; Figure 1).

Soluble NDF was highest $(P<0.001)$ in alfalfa haylage $(8.5 \%)$, lower for corn silage $(2.3 \%)$, and $0 \%$ for pearl millet silage. Potentially degradable NDF was similarly high for corn silage and pearl millet silage, (83.7 and $82.2 \%$, respectively), and lower $(P<0.001)$ for alfalfa haylage $(35.1 \%)$. Fractional disappearance rates of NDF were similar for alfalfa haylage and pearl millet silage (3.4 and $2.9 \% / \mathrm{h}$, respectively) and lower $(P<0.001)$ for corn silage $(1 \% / \mathrm{h})$. Pearl millet silage had the highest $(P<0.001)$ ED of NDF $(37.3 \%)$ followed by alfalfa haylage and corn silage $(27.0$ and $21.9 \%$, respectively).

In situ DM solubility reflected differences in the NFC content of the silages $(49.9,24.4$, and $13.3 \%$ for corn silage, alfalfa haylage, and pearl millet silage, respectively) and affected ED of forage DM. The higher DM ED of corn silage versus pearl millet silage is consistent with the higher DM apparent digestibility of CSD versus PMD. The higher ED of NDF for the pearl millet silage was likely due to its lower lignin content, as a percentage of NDF, compared with corn silage and agrees with the increased NDF apparent digestibility of the PMD treatment. Mustafa et al. (2004) observed similar in situ NDF degradability measurements for first cutting BMR pearl millet forage, with $a, b$, and $c$ values of $2.2,77.2$, and $3.6 \%$, respectively. Diet of the cow in which in situ bags are incubated has an effect on degradation results (Vanzant et al., 1998), which may explain why NDF ED of BMR pearl millet silage from the current study was lower than the NDF ED of BMR pearl millet forage reported by Mustafa et al. (2004), which averaged $44.2 \%$ when calculated using a $3 \% / \mathrm{h}$ passage rate.

\section{N Utilization}

Nitrogen intake (Table 6) was not significantly affected by diet, but $\mathrm{N}$ excretion in both urine and feces appeared to be higher $(P \leq 0.01)$ for PMD. Milk $\mathrm{N}$ secretion was higher $(P=0.02)$ in CSD compared with PMD. Excretion of urinary purine derivatives, allantoin 
Table 6. Effect of pearl millet silage on nitrogen utilization and urinary purine derivatives in lactating dairy cows

\begin{tabular}{|c|c|c|c|c|}
\hline \multirow[b]{2}{*}{ Item } & \multicolumn{2}{|c|}{$\operatorname{Diet}^{1}$} & \multirow[b]{2}{*}{$\mathrm{SEM}^{2}$} & \multirow[b]{2}{*}{ Diet $P$-value } \\
\hline & CSD & PMD & & \\
\hline $\mathrm{N}$ intake, $\mathrm{g} / \mathrm{d}$ & 778 & 790 & 15.6 & 0.23 \\
\hline $\mathrm{N}$ excretion or secretion, $\mathrm{g} / \mathrm{d}$ & 738 & 778 & 18.0 & 0.01 \\
\hline Urine $\mathrm{N}, \mathrm{g} / \mathrm{d}$ & 229 & 254 & 8.7 & 0.01 \\
\hline Urinary urea $\mathrm{N}, \mathrm{g} / \mathrm{d}$ & 161 & 187 & 6.0 & $<0.001$ \\
\hline Fecal N, g/d & 278 & 302 & 7.5 & 0.006 \\
\hline Total excreta N, g/d & 507 & 555 & 13.8 & 0.001 \\
\hline Milk N, g/d & 231 & 222 & 5.9 & 0.02 \\
\hline \multicolumn{5}{|c|}{$\mathrm{N}$ excretion or secretion, $\%$ of $\mathrm{N}$ intake } \\
\hline Urine $\mathrm{N}$ & 29.4 & 32.2 & 0.88 & 0.02 \\
\hline Fecal N & 35.7 & 38.2 & 0.55 & 0.003 \\
\hline Total excreta $\mathrm{N}$ & 65.1 & 70.5 & 0.96 & $<0.001$ \\
\hline Milk N & 29.8 & 28.2 & 0.62 & 0.001 \\
\hline Urine output, ${ }^{3} \mathrm{~kg} / \mathrm{d}$ & 21.4 & 26.6 & 0.70 & $<0.001$ \\
\hline \multicolumn{5}{|l|}{ Urinary $\mathrm{PD}^{4}$ excretion, $\mathrm{mmol} / \mathrm{d}$} \\
\hline Allantoin & 667 & 698 & 21.0 & 0.15 \\
\hline Uric acid & 86 & 88 & 4.2 & 0.51 \\
\hline Total PD & 753 & 786 & 24.3 & 0.17 \\
\hline
\end{tabular}

${ }^{1} \mathrm{CSD}=$ corn silage control diet; PMD = pearl millet silage diet.

${ }^{2}$ Largest SEM published in table; $\mathrm{n}=33$ ( $\mathrm{n}$ represents the number of observations used in the statistical analysis).

${ }^{3}$ Estimated from urine creatinine concentration, assumed to be excreted at $29 \mathrm{mg} / \mathrm{kg}$ of BW.

${ }^{4} \mathrm{PD}=$ purine derivatives.

and uric acid, was not different between diets. These urinary compounds have been used as an indirect indicator of ruminal microbial protein synthesis (Chen, 1989). Urinary urea $\mathrm{N}$ excretion was higher $(P \leq 0.001)$ with PMD, probably due to the higher concentrations of ammonia in the pearl millet silage not being incorporated into microbial protein before being absorbed by the rumen wall. It is also plausible that the $\mathrm{CP}$ of the pearl millet silage was truly less digestible than the corn silage $\mathrm{CP}$ because the neutral detergent insoluble $\mathrm{CP}$ was $1.17 \%$ in the pearl millet silage versus $0.50 \%$ in the corn silage. The PMD treatment had lower $(P$ $<0.001)$ milk $\mathrm{N}$ use efficiency and higher $(P \leq 0.02)$ total $\mathrm{N}$ excretion as a percentage of $\mathrm{N}$ intake. This can be detrimental to the environment, and $\mathrm{N}$ use efficiency might be improved by reducing supplemental $\mathrm{CP}$ sources when incorporating a higher $\mathrm{CP}$ forage, such as pearl millet silage, in dairy diets (O'Mara et al., 1998; Bernard et al., 2002).

\section{Enteric $\mathrm{CH}_{4}$ and $\mathrm{CO}_{2}$ Emissions}

Enteric $\mathrm{CH}_{4}$ and $\mathrm{CO}_{2}$ emission results are shown in Table 7. No differences were observed in $\mathrm{CO}_{2}$ emissions, which predominantly originate from bovine cellular respiration and to a much lesser degree from enteric

Table 7. Effect of pearl millet silage on carbon dioxide $\left(\mathrm{CO}_{2}\right)$ and methane $\left(\mathrm{CH}_{4}\right)$ emissions ${ }^{1}$ in lactating dairy cows

\begin{tabular}{|c|c|c|c|c|}
\hline \multirow[b]{2}{*}{ Item } & \multicolumn{2}{|c|}{$\operatorname{Diet}^{2}$} & \multirow[b]{2}{*}{$\mathrm{SEM}^{3}$} & \multirow[b]{2}{*}{ Diet $P$-value } \\
\hline & CSD & PMD & & \\
\hline $\mathrm{CO}_{2}, \mathrm{~kg} / \mathrm{d}$ & 13.6 & 14.0 & 0.42 & 0.24 \\
\hline $\mathrm{CH}_{4}, \mathrm{~g} / \mathrm{d}$ & 396 & 454 & 18.4 & $<0.001$ \\
\hline $\mathrm{CH}_{4},{ }^{4} \mathrm{~g} / \mathrm{kg}$ of DMI & 13.8 & 15.7 & 0.54 & $<0.01$ \\
\hline $\mathrm{CH}_{4}, 4 \mathrm{~g} / \mathrm{kg}$ of ECM & 8.28 & 9.58 & 0.386 & $<0.01$ \\
\hline
\end{tabular}

${ }^{1}$ Rumen gas emissions were measured using GreenFeed (C-Lock Technology Inc., Rapid City, SD). Data were derived from 8 individual measurements staggered over a 3-d period.

${ }^{2} \mathrm{CSD}=$ corn silage control diet; PMD = pearl millet silage diet.

${ }^{3}$ Largest SEM published in table; $\mathrm{n}=30$ ( $\mathrm{n}$ represents the number of observations used in the statistical analysis).

${ }^{4}$ Based on DMI and ECM yield data during the 3-d sampling periods. 
fermentation (Hammond et al., 2016). Dairy cattle $\mathrm{CO}_{2}$ emissions have been correlated with DMI, milk production, and metabolic BW, which were similar between treatments in this study (Kirchgessner et al., 1991; Kinsman et al., 1995). Daily enteric $\mathrm{CH}_{4}$ production, yield (i.e., per kilogram of DMI), and intensity (i.e., per kilogram of ECM) were all increased $(P<0.01)$ by PMD compared with CSD. Total daily enteric $\mathrm{CH}_{4}$ production of the cows in the current study was high because of their high DMI (Knapp et al., 2014) but within the range of values reported by Hristov et al. (2015b) for high-producing Holstein cows. Both diets had lower $\mathrm{CH}_{4}$ yield and intensity than previous work conducted by the authors (Harper et al., 2017a,b) due to the high MY and early stage of lactation of the cows.

The increase in enteric $\mathrm{CH}_{4}$ production with $\mathrm{PMD}$ is not beneficial to the environment and has to be accounted for in the context of whole-farm greenhouse gas emissions balance. Decreased diet digestibility and increased fiber content have been shown to increase enteric $\mathrm{CH}_{4}$ emission intensity (Mc Geough et al., 2010). Interestingly, O'Neill et al. (2011) reported a decrease in enteric $\mathrm{CH}_{4}$ production, yield, and intensity from dairy cattle grazing high-quality perennial ryegrass compared with a TMR. In that study, the perennial ryegrass had a higher NDF content but also a higher OM digestibility, suggesting that diet digestibility might have a stronger influence than total diet NDF content on enteric $\mathrm{CH}_{4}$ emissions. In the current study, PMD decreased apparent $\mathrm{OM}$ digestibility and had a higher fiber content, which explains the increase in enteric $\mathrm{CH}_{4}$ emissions. The higher enteric $\mathrm{CH}_{4}$ emissions for PMD may have decreased the available energy for milk production in that diet (Johnson and Johnson, 1995), which may help explain the decrease in MY with PMD.

\section{CONCLUSIONS}

Pearl millet silage included at $10 \%$ of dietary DM supported a high level of milk production in peaklactation dairy cows, did not decrease DMI, and maintained ECM yield compared with a corn silage-based control diet. The pearl millet diet tended to increase milk fat content and increased NDF digestibility but decreased OM digestibility. The fiber of pearl millet silage is highly digestible and replaces corn silage fiber well. However, pearl millet silage cut early, as in this experiment, lacks the starch that is removed from the diet when replacing corn silage. In practical rations, a diet containing pearl millet silage would likely have to be balanced for NFC and CP to maintain milk production and better utilize $\mathrm{N}$ in high-producing cows. Pearl millet shows promise as forage that could help diversify crop rotations, particularly on dairy farms in the northeastern United States.

\section{ACKNOWLEDGMENTS}

This project was supported by the Northeast Sustainable Agriculture Research and Education (SARE) program of the National Institute of Food and Agriculture, USDA (Washington, DC). The authors thank the staff of Farm Operations and Services of The Pennsylvania State University (University Park) for growing and harvesting the crops fed in our experiment. We also thank the staff of the Pennsylvania State University's Dairy Teaching and Research Center for their conscientious care of the experimental cows.

\section{REFERENCES}

Amer, S., and A. F. Mustafa. 2010. Short communication: Effects of feeding pearl millet silage on milk production of lactating dairy cows. J. Dairy Sci. 93:5921-5925. https://doi.org/10.3168/jds.2010 $-3279$.

AOAC International. 2000. Official Methods of Analysis. 17th ed. AOAC International, Arlington, VA.

AOAC International. 2006. Official Methods of Analysis. 18th ed. AOAC International, Arlington, VA.

Bernard, J. K., J. W. West, and D. S. Trammell. 2002. Effect of replacing corn silage with annual ryegrass silage on nutrient digestibility, intake, and milk yield for lactating dairy cows. J. Dairy Sci. $85: 2277-2282$

Brunette, T., B. Baurhoo, and A. F. Mustafa. 2014. Replacing corn silage with different forage millet silage cultivars: Effects on milk yield, nutrient digestion, and ruminal fermentation of lactating dairy cows. J. Dairy Sci. 97:6440-6449. https://doi.org/10.3168/ jds.2014-7998.

Brunette, T., B. Baurhoo, and A. F. Mustafa. 2016. Effects of replacing grass silage with forage pearl millet silage on milk yield, nutrient digestion, and ruminal fermentation of lactating dairy cows. J. Dairy Sci. 99:269-279. https://doi.org/10.3168/jds.2015-9619.

Bucholtz, H. F., C. L. Davis, D. L. Palmquist, and K. A. Kendall. 1969. Study of the low-fat milk phenomenon in cows grazing pearl millet pastures. J. Dairy Sci. 52:1388-1394.

Charbonneau, E., D. Pellerin, and G. R. Oetzel. 2006. Impact of lowering dietary cation-anion difference in nonlactating dairy cows: A meta-analysis. J. Dairy Sci. 89:537-548.

Chen, X. B. 1989. Excretion of purine derivatives by cattle and sheep and its use for the estimation of absorbed microbial protein. $\mathrm{PhD}$ dissertation. Aberdeen University, UK.

Chen, X. B., Y. K. Chen, M. F. Franklin, E. R. Ørskov, and W. J. Shand. 1992. The effect of feed intake and body weight on purine derivative excretion and microbial protein supply in sheep. J. Anim. Sci. 70:1534-1542.

Cherney, D. J. R., J. A. Patterson, and K. D. Johnson. 1990. Digestibility and feeding value of pearl millet as influenced by the brownmidrib, low-lignin trait. J. Anim. Sci. 68:4345-4351.

Cherney, J. H., D. J. R. Cherney, D. E. Akin, and J. D. Axtell. 1991. Potential of brown-midrib, low-lignin mutants for improving forage quality. Adv. Agron. 46:157-198. https://doi.org/10.1016/S0065 -2113(08)60580-5.

DuBois, M., K. A. Gilles, J. K. Hamilton, P. A. Rebers, and F. Smith. 1956. Colorimetric method for determination of sugars and related substances. Anal. Chem. 28:350-356.

Gillespie, J., R. Nehring, C. Sandretto, and C. Hallahan. 2010. Forage outsourcing in the dairy sector: The extent of use and impact on farm profitability. Agric. Resour. Econ. Rev. 39:399-414. 
Goering, H. K., and P. J. Van Soest. 1970. Forage Fiber Analysis. USDA Agricultural Research Service handbook no. 379. U.S. Department of Agriculture, Washington, DC.

Grabber, J. H., D. R. Mertens, H. Kim, C. Funk, F. Lua, and J. Ralpha. 2009. Cell wall fermentation kinetics are impacted more by lignin content and ferulate cross-linking than by lignin composition. J. Sci. Food Agric. 89:122-129.

Hall, M. B. 2009. Determination of starch, including maltooligosaccharides, in animal feeds: Comparison of methods and a method recommended for AOAC collaborative study. J. AOAC Int. 92:42-49.

Hammond, K. J., L. A. Crompton, A. Bannink, J. Dijkstra, D. R Yanez-Ruiz, P. O'Kiely, E. Kebreab, M. A. Eugene, Z. Yu, K. J. Shingfield, A. Schwarm, A. N. Hristov, and C. K. Reynolds. 2016. Review of current in vivo measurement techniques for quantifying enteric methane emission from ruminants. Anim. Feed Sci. Technol. 219:13-30. https://doi.org/10.1016/j.anifeedsci.2016.05.018.

Harner, J. P., R. W. Hemken, J. H. Vandersall, N. A. Clark, and B. A. Schneider. 1969. Relationship of pearl millet to milk fat depression in dairy cows. I. Cation fertilization. J. Dairy Sci. 52:1244-1248.

Harper, M. T., J. Oh, F. Giallongo, J. C. Lopes, G. W. Roth, and A N. Hristov. 2017a. Using brown midrib 6 dwarf forage sorghum silage and fall-grown oat silage in lactating dairy cow rations. J. Dairy Sci. 100:5250-5265. https://doi.org/10.3168/jds.2017-12552.

Harper, M. T., J. Oh, F. Giallongo, G. W. Roth, and A. N. Hristov. 2017b. Inclusion of wheat and triticale silage in the diet of lactating dairy cows. J. Dairy Sci. 100:6151-6163. https://doi.org/10 $.3168 /$ jds.2017-12553

Harvatine, K. J., Y. R. Boisclair, and D. E. Bauman. 2009. Recent advances in the regulation of milk fat synthesis. Animal 3:40-54.

Hassanat, F., A. F. Mustafa, and P. Seguin. 2007. Effects of inoculation on ensiling characteristics, chemical composition and aerobic stability of regular and brown midrib millet silages. Anim. Feed Sci. Technol. 139:125-140. https://doi.org/10.1016/j.anifeedsci 2007.01.005.

Hristov, A. N., J. Oh, F. Giallongo, T. Frederick, H. Weeks, P. R. Zimmerman, R. A. Hristova, S. R. Zimmerman, and A. F. Branco. 2015a. The use of an automated system (GreenFeed) to monitor enteric methane and carbon dioxide emissions from ruminant animals. J. Vis. Exp. 103:e52904.

Hristov, A. N., J. Oh, F. Giallongo, T. W. Frederick, M. T. Harper, H. L. Weeks, A. F. Branco, P. J. Moate, M. H. Deighton, S. R. O. Williams, M. Kindermann, and S. Duval. 2015b. An inhibitor persistently decreased enteric methane emission from dairy cows with no negative effect on milk production. Proc. Natl. Acad. Sci. USA 112:10663-10668. https://doi.org/10.1073/pnas.1504124112.

Huhtanen, P., K. Kaustell, and S. Jaakkola. 1994. The use of internal markers to predict total digestibility and duodenal flow of nutrients in cattle given six different diets. Anim. Feed Sci. Technol. $48: 211-227$.

Ivan, S. K., R. J. Grant, D. Weakley, and J. Beck. 2005. Comparison of a corn silage hybrid with high cell-wall content and digestibility with a hybrid of lower cell-wall content on performance of Holstein cows. J. Dairy Sci. 88:244-254.

Johnson, K. A., and D. E. Johnson. 1995. Methane emissions from cattle. J. Anim. Sci. 73:2483-2492.

Kinsman, R., F. D. Sauer, H. A. Jackson, and M. S. Wolynetz. 1995. Methane and carbon dioxide emissions from dairy cows in full lactation monitored over a six-month period. J. Dairy Sci. 78:27602766.

Kirchgessner, M., W. Windisch, H. L. Muller, and M. Kreuzer. 1991. Release of methane and of carbon dioxide by dairy cattle. Agribiol. Res. 44:91-102.

Knapp, J. R., G. L. Laur, P. A. Vadas, W. P. Weiss, and J. M. Tricarico. 2014. Invited review: Enteric methane in dairy cattle production: Quantifying the opportunities and impact of reducing emissions. J. Dairy Sci. 97:3231-3261. https://doi.org/10.3168/jds .2013-7234

Krishnamoorthy, U., T. V. Muscato, C. J. Sniffen, and P. J. Van Soest. 1982. Nitrogen fractions in selected feedstuffs. J. Dairy Sci. $65: 217-225$.
Lechartier, C., and J. L. Peyraud. 2011. The effects of starch and rapidly degradable dry matter from concentrate on ruminal digestion in dairy cows fed corn silage-based diets with fixed forage proportion. J. Dairy Sci. 94:2440-2454.

Lee, C., A. N. Hristov, T. W. Cassidy, K. S. Heyler, H. Lapierre, G. A. Varga, M. J. de Veth, R. A. Patton, and C. Parys. 2012. Rumenprotected lysine, methionine, and histidine increase milk protein yield in dairy cows fed a metabolizable protein-deficient diet. J. Dairy Sci. 95:6042-6056.

Maman, N., D. J. Lyon, S. C. Mason, T. D. Galusha, and R. Higgins. 2003. Pearl millet and grain sorghum yield response to water supply in Nebraska. Agron. J. 95:1618-1624.

Mc Geough, E. J., P. O'Kiely, K. J. Hart, A. P. Moloney, T. M. Boland, and D. A. Kenny. 2010. Methane emissions, feed intake, performance, digestibility, and rumen fermentation of finishing beef cattle offered whole-crop wheat silages differing in grain content. J. Anim. Sci. 88:2703-2716

Mertens, D. R. 1985. Effect of fiber on feed quality for dairy cows Pages 209-224 in Proc. 46th Minnesota Nutrition Conference. Minnesota Agricultural Extension Service, St. Paul, MN.

Mertens, D. R. 2009. Maximizing forage use by dairy cows. Pages 303319 in Proc. 27th Annual Western Canadian Dairy Seminar. Red Deer, Alberta. University of Alberta, Edmonton, Alberta, Canada.

Messman, M. A., W. P. Weiss, P. R. Henderlong, and W. L. Shockey 1992. Evaluation of pearl millet and field peas plus triticale silages for midlactation dairy cows. J. Dairy Sci. 75:2769-2775.

Miller, R. W., R. W. Hemken, J. H. Vandersall, D. R. Waldo, M. Okamato, and L. A. Moore. 1965. Effect of feeding buffers to dairy cows grazing pearl millet or sudan grass. J. Dairy Sci. 48:13191323

Mustafa, A. F., F. Hassanat, and P. Seguin. 2004. Chemical composition and in situ ruminal nutrient degradability of normal and brown midrib forage pearl millet grown in southwestern Québec. Can. J. Anim. Sci. 84:737-740.

NRC (National Research Council). 2001. Nutrient Requirements of Dairy Cattle. 7th rev. ed. Natl. Acad. Press, Washington, DC.

Nielsen, T. S., K. Sejrsen, H. R. Andersen, P. Lund, and E. M. Straarup. 2004. Effect of silage type and energy concentration on conjugated linoleic acid (CLA) in milk fat from dairy cows. J. Anim. Feed Sci. 13(Suppl. 1):697-700.

O'Mara, F. P., J. J. Fitzgerald, J. J. Murphy, and M. Rath. 1998. The effect on milk production of replacing grass silage with maize silage in the diet of dairy cows. Livest. Prod. Sci. 55:79-87.

O'Neill, B. F., M. H. Deighton, B. M. O'Loughlin, F. J. Mulligan, T. M. Boland, M. O'Donovan, and E. Lewis. 2011. Effects of a perennial ryegrass diet or total mixed ration diet offered to springcalving Holstein-Friesian dairy cows on methane emissions, dry matter intake, and milk production. J. Dairy Sci. 94:1941-1951. https://doi.org/10.3168/jds.2010-3361.

Oba, M., and M. S. Allen. 1999. Evaluation of the importance of the digestibility of neutral detergent fiber from forage: Effects on dry matter intake and milk yield of dairy cows. J. Dairy Sci. 82:589596.

Ørskov, E. R., and C. Fraser. 1975. The effects of processing of barleybased supplements on rumen $\mathrm{pH}$, rate of digestion and voluntary intake of dried grass in sheep. Br. J. Nutr. 34:493-500.

Ørskov, E. R., and I. McDonald. 1979. The estimation of protein degradability in the rumen from incubation measurements weighted according to rate of passage. J. Agric. Sci. (Camb.) 92:499-503.

Rico, D. E., and K. J. Harvatine. 2013. Induction of and recovery from milk fat depression occurs progressively in dairy cows switched between diets that differ in fiber and oil concentration. J. Dairy Sci. 96:6621-6630.

Schneider, B. A., N. A. Clark, R. W. Hemken, and J. H. Vandersall. 1970. Relationship of pearl millet to milk fat depression in dairy cows. II. Forage organic acids as influenced by soil nutrients. J. Dairy Sci. 53:305-310.

Shingfield, K. J., C. K. Reynolds, B. Lupoli, V. Toivonen, M. P. Yurawecz, P. Delmonte, J. M. Griinari, A. S. Grandison, and D. E. Beever. 2005. Effect of forage type and proportion of concen- 
trate in the diet on milk fatty acid composition in cows given sunflower and fish oil. Anim. Sci. 80:225-238. https://doi.org/10 $.1079 / \mathrm{ASC} 41820225$.

Sjaunja, L. O., L. Baevre, L. Junkkarinen, J. Pedersen, and J. Setälä. 1990. A Nordic proposal for an energy corrected milk (ECM) formula. Pages 156-157 in Proc. 27th Session Int. Comm. Breeding Product. Milk Anim. Wageningen Acad. Publ., Wageningen, the Netherlands.

Thomison, P., P. Raul, R. Hammond, and R. Mullen. 2011. Managing risks in continuous corn. Accessed Dec. 28, 2017. https://agcrops .osu.edu/newsletters/2011/02.

Van Soest, P. J. 1994. Nutritional Ecology of the Ruminant. 2nd ed. Cornell University Press, Ithaca, NY.

Van Soest, P. J., J. B. Robertson, and B. A. Lewis. 1991. Methods for dietary fiber, neutral detergent fiber, and nonstarch polysaccharides in relation to animal nutrition. J. Dairy Sci. 74:3583-3597.

Vanzant, E. S., R. C. Cochran, and E. C. Titgemeyer. 1998. Standardization of in situ techniques for ruminant feedstuff evaluation. J. Anim. Sci. 76:2717-2729.

Vlaeminck, B., V. Fievez, A. R. J. Cabrita, A. J. M. Fonseca, and R. J. Dewhurst. 2006a. Factors affecting odd and branched-chain fatty acids in milk: A review. Anim. Feed Sci. Technol. 131:389-417.
Vlaeminck, B., V. Fievez, S. Tamminga, R. J. Dewhurst, A. van Vuuren, D. De Brabander, and D. Demeyer. 2006b. Milk odd- and branched-chain fatty acids in relation to the rumen fermentation pattern. J. Dairy Sci. 89:3954-3964.

Ward, J. D., D. D. Redfearn, M. E. McCormick, and G. J. Cuomo. 2001. Chemical composition, ensiling characteristics, and apparent digestibility of summer annual forages in a subtropical doublecropping system with annual ryegrass. J. Dairy Sci. 84:177-182.

Wolf, C. A. 2003. The economics of dairy production. Vet. Clin. North Am. Food Anim. Pract. 19:271-293.

Zegada-Lizarazu, W., and M. Iijima. 2005. Deep root water uptake ability and water use efficiency of pearl millet in comparison to other millet species. Plant Prod. Sci. 8:454-460.

Zened, A., F. Enjalbert, M. C. Nicot, and A. Troegeler-Meynadier. 2013. Starch plus sunflower oil addition to the diet of dry dairy cows results in a trans-11 to trans-10 shift of biohydrogenation. J. Dairy Sci. 96:451-459. 